\title{
Heavy Metal Distribution in the Vicinity of Automobile Scrap Sites in Agbor, Nigeria
}

\author{
${ }^{* 1}$ E.K. OSSAI \\ Department of Chemistry, Delta State University, Abraka \\ Phone number: $+234(0) 8035022797$
}

KEYWORDS: Vehicle scrap, heavy metals, soil concentration, Nigeria

\begin{abstract}
Surface soil in the vicinity of automobile scrap sites were studied for heavy metal level. The result revealed that the concentration of heavy metals in the various sites exceeded those of the control sites. The mean concentration ranges $\left(\mathrm{mg} \mathrm{kg}^{-1}\right)$ for heavy metals in these sites were $4.00-$ 11.55 for $\mathrm{Cd}$; 6.22 - 977 for $\mathrm{Pb} ; 0.34-1.26$ for $\mathrm{Cu}$; $0.72-1.59$ for $\mathrm{Cr}$ and $12.21-93.31$ for $\mathrm{Fe}$. However, the concentrations compared well with those found in normal agricultural soil and were below environmental quality criteria for soil for agriculture, residential and industrial purposes except for cadmium. The accumulation pattern for the metals followed the order $\mathrm{Fe}>\mathrm{Cd}>\mathrm{Pb}>\mathrm{Cr}>\mathrm{Cu}$. Cadmium represented a contamination hazards in these sites. @ JASEM
\end{abstract}

\section{http://dx.doi.org/10.4314/jasem.v18 i2.17}

Introduction: Soil pollution occurs in several ways, including application of herbicides, fertilizers, pesticides and industrial effluent. Other major sources including indiscriminate disposal of dry cell batteries, papers, textiles, oil and grease and metal scraps from mechanic workshops (Odukoya and Bamgbose, 2001). Toxic metals content in soil, leads to groundwater contamination while some may be absorbed by crops or washed into nearby streams and rivers through runoff (Nyle and Well, 1999).

Contamination of heavy metals in the environment is of major concern because of their toxicity and threat to human life and the environment (Iwegbue et al., 2006). Contrary to other pollutants, heavy metals are not biodegradable and tend to persist as metal atoms or the speciation may change overtime. Moreover, unexpected rapid mobilization of heavy metal could result in environmental catastrophe, menacing human health and welfare by poisoning water sources and food sources (Stiglini and Anderberg, 1993).

Like other major cities in Nigeria, automobile mechanic workshops are found scattered all over Agbor town and occupied almost every vacant lot among the major roads. Wastes were indiscriminately dumped on every available space and all categories of urban wastes ranging from lubricating oil films, junked cars to tires were found to litter along streets and major roads (Iwegbue et al., 2006).

Automobile mechanic works has been implicated for elevated concentration of heavy metals $(\mathrm{Cd}, \mathrm{Cr}, \mathrm{Cu}$, $\mathrm{Pb}, \mathrm{Ni}$ and $\mathrm{Zn}$ ) in soil profile in the vicinity of automobile mechanic waste dumps (Iwegbue et al., 2006). Assessing the concentrations of heavy metal in these sites provides information on guidance for redevelopment, extents of contamination and choice of possible remediation or clean-up techniques. The primary objective of the present study is to determine the characteristic

levels of iron, copper, chromium, lead and cadmium in soil in the vicinity of automobile scrap sites in Agbor town.

\section{METALS AND METHODS}

Description of study area: Agbor town lies between the latitude $5.10^{\circ}-6.2^{\circ} \mathrm{N}$ and longitude $6.10^{\circ}-6.2^{\circ}$ E. The town drains into the Ologodo River. The major industrial activities in this town are medium scale industries, steel and automobile mechanic works.

Sampling and analysis: Scrap sites were divided into $50 \mathrm{~m} \times 50 \mathrm{~m}$ quadrant and each quadrant was further subdivided into 25 sampling cells with an area of 10 m x $10 \mathrm{~m}$ each. Soil samples were collected from each cell at depth of $0-30 \mathrm{~cm}$ using a soil auger. A total of nine sites were examined with sites 03, 06 and 09 as the control sites. These sites do not have any known history of automobile waste dump. In our laboratory, the samples were air-dried, and sieved to pass a $2 \mathrm{~mm}$ nylon mesh. The samples were stored in plastic container at $4{ }^{\circ} \mathrm{C}$ prior to analysis. Five grams of the air-dried samples were digested with mixture of aqua-regia (Radojevic and Bashkin, 1999). The clear digest was diluted to $100 \mathrm{ml}$ mark using nanopure water. The solution was subsequently analyzed for $\mathrm{Fe}, \mathrm{Cu}, \mathrm{Cr}, \mathrm{Pb}$, and $\mathrm{Cd}$ using a graphite furnace atomic absorption spectrophotometer equipped with $\mathrm{D}_{2}$ background correction device (GBC scientific equipment Sensa X 1175, Australia).

Quality control was assured by the analyzed procedural blank replicates and spikes. All reagents used $\left(\mathrm{HCl}, \mathrm{HNO}_{3}\right)$ were of analytical grades. The spike recovery for each metal was greater than 93.5 $\%$. 


\section{RESULTS AND DISCUSSION}

Table 1 presents the concentrations of heavy metals in surface soils in the vicinity of automobile scrap sites in Agbor metropolis. The mean $\pm \mathrm{SD}$ is presented and range in parenthesis. The values below the means value represent the concentration range at each sites. Analysis of variance (ANOVA) $(\mathrm{P} \geq 0.05)$ represents significant spatial variation in the concentration of heavy metals in all sites. Each site shows significant higher concentration of $\mathrm{Cd}, \mathrm{Pb}, \mathrm{Cr}, \mathrm{Cu}$ and $\mathrm{Fe}$ than of the control sites. Control sites are devoid of automobile scrap wastes and other anthropogenic activities hence low levels of the studied metals. This further suggested that elevated concentrations of metals found in these sites were due to the contributions from the automobile scraps.

The concentrations of heavy metals were within the normal concentration ranges of these metals in most agricultural soils, except for Cd. According to the review by Lindsay (1979), Kabata-pendias and Pendias (1992), and Alloway (1995), normal concentration range of these elements in soil are 0.01 - $0.7 \mathrm{mgkg}^{-1}$ for $\mathrm{Cd}$; $1.00-10.0 \mathrm{mgkg}^{-1}$ for $\mathrm{Cr} ; 2$ $250 \mathrm{mgkg}^{-1}$ for $\mathrm{Cu}, 0.4-1000 \mathrm{mgkg}^{-1}$ for $\mathrm{Ni} ; 50-300$ $\mathrm{mgkg}^{-1}$ for $\mathrm{Pb}$ and $1-900 \mathrm{mgkg}^{-1}$ for $\mathrm{Zn}$. In comparison, the concentrations of heavy metal in the soil samples were generally lower than those found in the soil profiles of automobile mechanic waste dumps in Port Harcourt (Iwegbue et al., 2006) and soil in the vicinity of municipal solid waste dump in Southwestern Nigeria (Bamgbose et al., 1999) and levels reported for concentrated sites elsewhere in the world (Ma and Roa, 1997; Kabala and Singh, 2001; Szerzen et al., 1993).

The accumulation pattern of the heavy metals in the soil follows the order $\mathrm{Fe}>\mathrm{Cd}>\mathrm{Pb}>\mathrm{Cr}>\mathrm{Cu}$. This order is justified by the fact that iron constitutes about $80 \%$ of total content of the scraps dumped on the soil. The elevated level of lead found is due to used lead battery cells. In Nigeria, guideline and standards for redevelopment of contaminated soil is lacking hence most comparison shall be made with international guidelines.

The levels of metals found in these sites are below threshold values for each metal under the Interdepartmental Committee on the Redevelopment of Contaminated Land (ICRCL) scheme used in the United Kingdom (ICRCL, 1987, 1988). This implies that the concentration of these metals should cause a problem. In other word, it does not need any form of remedial action before any form of chosen development can proceed on such land. However, the levels of $\mathrm{Cd}$ exceeded the Canadian interim environmental quality criteria for agriculture and park lands/residential purposes (CCME, 1991). Such sites require remedial action for $\mathrm{Cd}$ before it can be used for either agricultural or residential purposes. Cadmium consist a serious contamination hazards in these sites. Cadmium can be easily mobilized in these sites because of the academic nature of soils in Southern Nigeria (Odu et al., 1987; Isirimah, 1987; Iwegbue et al., 2006). They may eventually contaminate the groundwater or nearby surface water or absorbed by plants which will finally get into human food chain.

Conclusion: The concentrations of heavy metals from this study were within concentrations found in normal agricultural soil and below the ICRCL threshold values and Canadian interim environmental quality criteria for agricultural, residential and industrial purposes except for $\mathrm{Cd}$. The results revealed that soil in these sites requires some remedial action for $\mathrm{Cd}$ before such land can be used for any form of chosen development.

Table 1: Mean \pm S.D and range (in parenthesis) of heavy metal concentration in $\mathrm{mg} / \mathrm{kg}$ dry weight from soil number.

\begin{tabular}{|c|c|c|c|c|c|c|}
\hline \multicolumn{2}{|c|}{ Sample } & \multirow{2}{*}{$\begin{array}{l}\mathbf{F e} \\
64.44 \pm 2.58^{\mathrm{a}} \\
(60.20-56.40)\end{array}$} & \multirow{2}{*}{$\begin{array}{l}\mathbf{C u} \\
0.29 \pm 0.03^{\mathrm{b}} \\
(0.19-0.41)\end{array}$} & \multirow{2}{*}{$\begin{array}{l}\mathbf{C r} \\
0.72 \pm 0.09^{\mathrm{b}} \\
(0.64-0.90)\end{array}$} & \multirow{2}{*}{$\begin{array}{l}\mathbf{P b} \\
9.77 \pm 1.47^{\mathrm{b}} \\
8.30-10.75)\end{array}$} & \multirow{2}{*}{$\begin{array}{l}\mathbf{C d} \\
8.44 \pm 1.01^{\mathrm{b}} \\
0.04-9.00)\end{array}$} \\
\hline 01 & 25 & & & & & \\
\hline 02 & 25 & $\begin{array}{l}93.31 \pm 4.67^{\mathrm{b}} \\
(90.40-98.60)\end{array}$ & $\begin{array}{l}0.34 \pm 0.05^{\mathrm{b}} \\
(0.24 \pm 0.04)\end{array}$ & $\begin{array}{l}1.18 \pm 0.15 \\
(0.84-1.32)\end{array}$ & $\begin{array}{l}7.11 \pm 1.13^{b} \\
(6.00-8.22)\end{array}$ & $\begin{array}{l}1.55 \pm 1.39^{\mathrm{a}} \\
(11.05-12.60)\end{array}$ \\
\hline 03 & 25 & $\begin{array}{l}3.00 \pm 0.15 \\
(1.95-3.50)\end{array}$ & $\begin{array}{l}0.1 \pm 0.01 \\
(0.09-0.22)\end{array}$ & $\begin{array}{l}0.21 \pm 0.02 \\
(0.08-0.43)\end{array}$ & $\begin{array}{l}44 \pm 0.08^{b} \\
44-0.07^{b}\end{array}$ & $\begin{array}{l}1.77 \pm 0.14^{\mathrm{b}} \\
(1.10-1.95)\end{array}$ \\
\hline 04 & 25 & $\begin{array}{l}67.80 \pm 3.39^{\mathrm{b}} \\
(62.00-70.50)\end{array}$ & $\begin{array}{l}0.66 \pm 0.07^{\mathrm{b}} \\
(0.44-0.90)\end{array}$ & $\begin{array}{l}1.44 \pm 0.19^{\mathrm{b}} \\
(1.22-1.96)\end{array}$ & $\begin{array}{l}6.22 \pm 0.31^{\mathrm{b}} \\
(5.96-6.66)\end{array}$ & $\begin{array}{l}9.77 \pm 1.27^{\mathrm{b}} \\
(8.99-10.86)\end{array}$ \\
\hline 05 & 25 & $\begin{array}{l}90.00 \pm 4.50^{\mathrm{b}} \\
(85.00 \pm 100.05)\end{array}$ & $\begin{array}{l}1.38 \pm 0.01 \\
(1.08-1.68)\end{array}$ & $\begin{array}{l}1.59 \pm 0.23^{\mathrm{b}} \\
(1.40-2.09)\end{array}$ & $\begin{array}{l}8.88 \pm 1.48 \\
(7.84-0.91)\end{array}$ & $\begin{array}{l}7.55 \pm 0.91^{\mathrm{b}} \\
(6.95-8.65)\end{array}$ \\
\hline 0.6 & 25 & $\begin{array}{l}35.66 \pm 2.14^{\mathrm{b}} \\
(3.40-38.92)\end{array}$ & $\begin{array}{l}0.31 \pm 0.13^{\mathrm{b}} \\
(0.09-0.43)\end{array}$ & $\begin{array}{l}0.31 \pm 0.06^{\mathrm{b}} \\
(0.11-0.50)\end{array}$ & $\begin{array}{l}1.77 \pm 0.20^{\mathrm{b}} \\
(1.28-1.99)\end{array}$ & ND \\
\hline 07 & 25 & $\begin{array}{l}12.21 \pm 0.97^{\mathrm{b}} \\
10.21-14.08)\end{array}$ & $\begin{array}{l}0.74 \pm 0.9^{\mathrm{b}} \\
(0.64-0.92)\end{array}$ & $\begin{array}{l}1.31 \pm 0.23^{\mathrm{b}} \\
(0.01-1.52)\end{array}$ & $\begin{array}{l}8.00 \pm 1.12^{\mathrm{b}} \\
(6.95-9.05)\end{array}$ & $\begin{array}{l}4.00 \pm 0.60^{\mathrm{b}} \\
(3.80-4.88)\end{array}$ \\
\hline 08 & 25 & $\begin{array}{l}78.91 \pm 3.95^{\mathrm{b}} \\
(69.0-80.91)\end{array}$ & $\begin{array}{l}1.26 \pm 0.16^{\mathrm{b}} \\
(1.06-1.48)\end{array}$ & $\begin{array}{l}1.8 \pm 0.18 \\
(1.00-1.38)\end{array}$ & $\begin{array}{l}9.33 \pm 1.30^{\mathrm{b}} \\
(7.86-10.00)\end{array}$ & $\begin{array}{l}4.88 \pm 0.78^{\mathrm{b}} \\
(4.06-5.50)\end{array}$ \\
\hline 09 & 25 & $\begin{array}{l}23 / 31 \pm 1.41^{\mathrm{b}} \\
(20.01-26.51)\end{array}$ & $\begin{array}{l}0.09 \pm 0.01^{\mathrm{b}} \\
(0.04-0.15)\end{array}$ & $\begin{array}{l}0.91 \pm 0.439 \\
(0.62-1.20)\end{array}$ & $\begin{array}{l}0.44 \pm 0.09^{b} \\
(0.22-0.66)\end{array}$ & $\begin{array}{l}1.33 \pm 0.35^{\mathrm{a}} \\
(1.10-1.65)\end{array}$ \\
\hline
\end{tabular}




\section{REFERENCES}

Alloway, B. J (1995). Heavy metals in soils, $2^{\text {nd }}$ Ed. Wiley, New York.

Bambose, O., Odukoya O. and Arowolo, T. O. A. (1999). Earthworms as bio-indicator of heavy metal pollution in dumpsite of Abeokuta city, Nigeria. $\quad$ http://rbt.os.ac.cr/revistes/48$\underline{\text { 1/zoobamb.htm;pp-7 }}$

Canada Council of Minister of Environment (CCME) 1991. Interim Canadian Environment Quality Criteria for contaminated sites, report CCEM, EPCC534, Winnipeg, Monitoba.,

Interdepartmental Committee for the Redevelopment of Contaminatated Lands (1987). Guidance on the assessment and redevelopment of contaminated land. ICRCL paper 58/83, $2^{\text {nd }}$ Ed. Department of Environment, London.

Isirimah, N. O. (1987). An inventory of some chemical properties of selected surface soil of Rivers States of Nigeria, pp 217 - 233. In proceeding of 15" Annual conference of soil science association of Nigeria, Kaduna.

Iwegbue, C. M. A; Isirimah, N. O.; Igwe, C. and Williams E. S. (2006). Characteristic levels of heavy metals in soil profiles of automobile mechanic waste dumps in Nigeria. Environmentalist. 26: 123 - 128.

Kabala and Singh, R. B. (2001). Fraction and mobility of copper, Lead and Zinc in soil profiles in vicinity of a copper smelter. J. Environ. Qual. 30: $4845-492$.

Lindsay,W. I (1979). Chemical equilibria in soils. Wiley New York.
Ma, L. Q. and Roa, G. N.P. (1997). Chemical fractional of cadmium, nickel and zinc in contaminated soils. J. Envoron. Qual. 20: 259 264.

Nyle, C. B. and Weil R (1999). The mutiny and properties of soil, $20^{\text {th }} \mathrm{Ed}$. Prentice Hall, USA.

Odu, C. T. I., Esunioso, O. F. Nwoboshi, L.C. and Ogunwale J. A. (1985). Environmental study (soil and vegetation) of Nigerian Agip Oil Company operation areas. A report submitted to Nigerian Agip Oil Company Ltd, Lagos.

Odukoya, O. and Bamgboye, O. (2001). Heavy metals in top soils of Abeokkuta dumpsites. Global J. Appi. Set. 1: $467-472$.

Purves, D. (1985). Trace-element contamination of environment. Elsevier Amsterdam.

Radojevic, M. and Bashkin, V.N. (1999). Practical Environmental Analysis. Royal Society of Chemistry, Cambridge.

Stiglini, W. M. and Anderberg, S. (1993). Heavy metal pollution in Rhine Basin. Eviron. Set Technol. 27: 786 - 793.

Szetsezen, L. Chodak, T. ad Karczensska, A (1993). Areal, profile and time differentiation of heavy metals content in soils in the vicinity of copper smeller in $160 \mathrm{~m}$ Polad, pp. 279 - 281. In H.J.P. Ejijakers (ed) integrated oil and sediment research. Kiuwer Academic Pubisher Dordrecht, the Netherlands. 